\title{
PENGARUH VIDEO EDUKASI TERHADAP PENGETAHUAN PENCEGAHAN HIV/AIDS DI LAPAS YOGYAKARTA
}

\author{
Brigitta Ayu Dwi Susanti \\ Program Studi D-III Keperawatan, Sekolah Tinggi Kesehatan Notokusumo Yogyakarta, Indonesia \\ email: brigittaayudwisusanti@gmail.com
}

\begin{abstract}
Abstrak
Lembaga Pemasyarakatan merupakan suatu lembaga yang berada di bawah naungan Kementerian Hukum dan Hak Asasi Manusia. Pada Lembaga Pemasyarakatan Yogyakarta terdapat napi dengan kasus HIV/AIDS. Bagi napi lainnya yang tidak terkena HIV AIDS belum mengenal bagaimana pencegahan terhadap penyakit tersebut sehingga penting adanya suatu metode dengan Video Edukasi dalam pencegahan HIV/AIDS. Tujuan penelitian ini adalah untuk mengetahui apakah terdapat pengaruh program video edukasi terhadap pencegahan HIV/AIDS di lembaga pemasyarakatan. Penelitian ini menggunakan metode penelitian Quasy Experiment pre and post design without controlled group. Analisis data yang digunakan dalam penelitian ini menggunakan uji wilxocon. Hasil dalam penelitian ini adalah ada pengaruh pemberian video edukasi HIV AIDS terhapat peningkatan pengetahuan napi di Lapas Yogyakarta ( $p<0,05)$. Sehingga dapat disimpulkan bahwa video edukasi tentang HIV/AIDS di lembaga pemasyarakatan dapat meningkatkan pengetahuan pencegahan HIV/AIDS.
\end{abstract}

Kata kunci : HIV/AID, lapas, video edukasi

Abstract

Penitentiary is an institution under the auspices of the Ministry of Law and Human Rights. In the correctional institution in Yogyakarta there are prisoners with HIV / AIDS cases. For other prisoners who are not affected by HIV AIDS do not know how to prevent the disease so it is important to have a method with "Educational Videos" to prevent of HIV / AIDS. The purpose of this study was to determine whether there was an effect of educational video programs on HIV / AIDS prevention in prisons. This study used the Quasy Experiment research method pre and post design without a controlled group. The data analysis used in this study used Wilcoxon test analysis. The results of this study were that there was an effect of giving HIV AIDS educational videos on the increase in the knowledge of prisoners in the Yogyakarta Prison ( $p$ $<0.05)$. So it can be concluded that educational videos about HIV / AIDS in prisons can increase knowledge of HIV / AIDS prevention.

Keywords : HIV/AID, prisons, educational video

\section{PENDAHULUAN}

Jumlah penderita HIV (Human Immunodeficiency Virus) dan AIDS (Acquired Immune Deficiency Syndrome) sangat memperihatinkan yaitu hampir 78 juta orang telah terinfeksi virus HIV dan sekitar 39 juta orang telah meninggal dengan HIV di dunia. Pada tahun 2013 jumlah kasus orang dengan HIV adalah 35 juta, dan jika dibandingkan pada tahun 2001 sebanyak 29,8 juta. Diperkirakan 0,8\% dari orang dewasa berusia 15-49 tahun di seluruh dunia hidup dengan HIV (Machfoedz, 2009). Faktanya 19 juta dari 35 juta orang yang hidup dengan HIV saat ini tidak tahu bahwa mereka terinfeksi virus HIV. Kasus HIV dan AIDS di Indonesia sebanyak 859 kasus sampai 21.591 kasus pada tahun 2004 (Setiana, 2005). Namun, hal ini menunjukkan jumlah kasus AIDS menunjukkan jumlah yang fluktuatif sejak tahun 2012. Jumlah kumulatif penderita HIV dari tahun 1987 sampai September 2014 sebanyak 150.296 orang, sedangkan total kumulatif kasus AIDS sebanyak 55.799 orang (Monks, 2004).

Permasalahan kesehatan HIV dan AIDS dapat terjadi pada siapapun tanpa memandang status seseorang dalam masyarakat seperti narapidana laki-laki atau perempuan. Berdasarkan penelitian, 
prevalensi penularan HIV dan Sifilis pada narapidana pria $1,1 \%$ dan $5,1 \%$ sedangkan pada narapidana perempuan lebih tinggi yaitu mencapai $6 \%$ dan $8,5 \%$. Pendidikan kesehatan tentang HIV dan AIDS bagi narapidana sangat penting dilakukan karena untuk menekan angka kejadian penularan HIV dan AIDS di lapas yang mengalami peningkatan setiap tahunnya (Ergene, 2005). Pendidikan kesehatan berupa upaya persuasif atau pembelajaran kepada sasaran agar melakukan tindakan pencegahan yang didasarkan pada pengetahuan dan kesadaran yang diperoleh setelah mendapatkan pendidikan kesehatan. Pendidikan kesehatan merupakan upaya kesehatan masyarakat yang bertujuan untuk mengubah perilaku seseorang sehingga dapat tercapai pencegahan penyakit dan peningkatan derajat kesehatan masyarakat. Pentingnya metode video edukasi sangat didukung pada keadaan pandemi seperti sekarang ini. Pendidikan kesehatan melalui video edukasi di Lapas sangat bermanfaat bagi program penanggulangan HIV dan AIDS, karena aspek informasi dan pengetahuan berperan bagi seseorang untuk mencegah dirinya terkena infeksi, karena pengetahuan, sikap, dan perilaku seksual memiliki keterkaitan erat (Vaz, 1996).

Lembaga Pemasyarakatan atau Lapas merupakan suatu lembaga yang berada di bawah naungan Kementerian Hukum dan Hak Asasi Manusia. Lembaga tersebut disediakan oleh pemerintah untuk menampung orang-orang yang melanggar hukum yang berlaku di Indonesia. Adapun tujuan didirikannya LP bukan untuk melakukan penyiksaan terhadap para pelanggar hukum, melainkan untuk melakukan pembinaan, baik secara lahir maupun batin (Sholihatun, 2011). Berdasarkan data yang didapat dari hasil wawancara dengan dengan pengelola lapas di Yogyakarta, jumlah narapidana HIV AIDS di LP sebanyak 3 orang. Menurut Tn.X salah satu narapidana di LP tersebut yang menderita HIV/AIDS, berstatus sebagai narapidana saja adalah hal yang memalukan bagi dirinya dan orang-orang sekitar yang mengenalnya, apalagi ditambah dengan statusnya yang dinyatakan HIV positif membuat dirinya semakin khawatir akan dikucilkan orang lain. Napi lain menganggap bahwa HIV/AIDS sebagai penyakit yang masih asing.

Seseorang yang terjangkit infeksi HIV /AIDS menyebabkan sistem kekebalan menjadi semakin lemah. Keadaan ini akan membuat orang mudah diserang oleh beberapa jenis penyakit (sindrom) yang kemungkinan tidak memengaruhi orang dengan sistem kekebalan tubuh yang sehat. Penyakit tersebut disebut sebagai infeksi oportunistik. Infeksi oportunistik termasuk jamur pada mulut, jenis kanker yang jarang, dan penyakit tertentu pada mata, kulit dan sistem saraf (Hartoyo, 2013). Tujuan penelitian ini adalah untuk mengetahui pengaruh video edukasi terhadap pencegahan HIV AIDS di Lapas Yogyakarta.

\section{METODE PENELITIAN}

Rancangan penelitian yang digunakan dalam penelitian ini adalah penelitian kuantitatif dengan quasi eksperimen dengan rancangan pre test - post test without control group. Berikut desain penelitian:

\begin{tabular}{llll}
\hline Responden $\mathrm{n}=31$ & $\mathrm{O} 1$ & $\mathrm{X}$ & $\mathrm{O} 2$ \\
\hline
\end{tabular}

Gambar 1. Rancangan Penelitian

Keterangan :

$\mathrm{O} 1=$ Pre-test

$\mathrm{O} 2$ = Post-test

$\mathrm{X}=$ Intervention

Hasil perhitungan validitas instrument diperoleh nilai $r>0,444$. Hasil perhitungan pada kuesioner pengetahuan terdapat 21 soal valid yang sudah diuji. Sehingga kuesioner dapat digunakan. Kuesioner yang telah dilakukan uji validitas kemudian dilakukan uji reliabilitas menggunakan Alpha Cronbach dengan bantuan software komputer. Pada hasil uji reliabilitas penelitian ini, semua butir soal untuk pengukuran pengetahuan dan sikap dinyatakan reliabel dengan nilai Alpha Cronbach 0,960 untuk pengetahuan. Penelitian kuantitatif dengan desain quasi eksperimen dengan rancangan pre test-post test maka populasi dan sampel yang 
digunakan adalah: Populasi dari penelitian ini adalah semua napi berjumlah 116 di lapas Yogyakarta.

Teknik pengambilan sampel dalam penelitian ini menggunakan teknik non probability sampling yaitu consecutive sampling, dengan kriteria inklusi: a. dapat membaca, melihat, dan menulis serta berkomunikasi dengan baik, b. Usia 17 tahun sampai 60 tahun, c. pasien tidak sedang mengalami komplikasi lain dari penyakit yang diderita seperti jantung atau gagal ginjal dan penyakit kejiwaan.

Adapun kriteria eksklusi meliputi: a. pasien sedang di dalam masa pengobatan tertentu, b. pasien menolak untuk menjadi responden. Besar sampel yang diperoleh adalah 31 sampel.

Pelaksanaan penelitian dilakukan pada bulan Agustus 2020. Penelitian dilaksanakan selama dua hari. Hari pertama, peneliti berdiskusi dengan pihak lapas untuk menetukan jadwal penelitian. Meliputi apersepsi dengan pihak LP tentang mekanisme pelaksanaan penelitian dan menyampaikan surat ijin dari Kemenkumham. Hari kedua pelaksanaan meliputi kegiatan pretest, dilanjutkan pemutaran video edukasi dan diakhiri post test. Pelaksanaan dibantu oleh asisten peneliti.

\section{HASIL DAN PEMBAHASAN}

Seluruh responden berjenis kelamin laki-laki karena lapas diperuntukkan untuk tahanan laki-laki. Karakteristik usia terbanyak ada paa kategori cukup yaitu pada usia 17 tahun, dimana menurut pengalaman merupakan faktor yang dapat mempengaruhi seseorang dalam menyerap informasi kesehatan yang diberikan. Usia responden yang telah mencapai remaja menunjukkan bahwa responden telah mengalami berbagai pengalaman dalam hidupnya (Widyastuti, 2009). Semakin meningkat usia seseorang, maka semakin matang fungsi inderanya dan semakin pula banyak pengalaman sendiri maupun orang lain yang ada di sekitarnya dapat memperluas pengetahuan seseorang (Ritianawati, 2010).

Menurut (Taher, 2013), pengalaman merupakan faktor yang dapat mempengaruhi seseorang. Usia responden yang telah mencapai usia minimal remaja menunjukkan bahwa remaja telah mengalami berbagai pengalaman semasa hidupnya. Hal ini sesuai dengan penelitian Septiana (2012) tentang Pendidikan Seks yang diperoleh di labschool Jakarta Selatan.

Tingkat Pengetahuan tentang HIV/AIDS pada saat Pretest adalah sebagai berikut:

Tabel 1. Tingkat Pengetahuan Tentang HIV/AIDS pada saat Pretest dan Posttest di Lapas Cebongan tahun 2020

\begin{tabular}{lrrrr}
\multicolumn{1}{c}{ Tingkat } & \multicolumn{2}{c}{ Pre test } & \multicolumn{2}{c}{ Post test } \\
Pengetahuan & $(\mathrm{N})$ & \multicolumn{1}{c}{$(\%)$} & \multicolumn{1}{c}{$(\mathrm{N})$} & \multicolumn{1}{c}{$(\%)$} \\
Baik & 1 & 3,22 & 25 & 80,64 \\
Cukup & 20 & 64,52 & 4 & 12,90 \\
Kurang & 10 & 32,26 & 2 & 6,45 \\
$\quad$ Total & 31 & 100,00 & 31 & 100,00 \\
\hline
\end{tabular}

Hasil penelitian menunjukkan bahwa tingkat pengetahuan tentang pencegahan HIV AIDS di lapas pada saat sebelum diberikan pendidikan kesehatan dengan media video tentang HIV/AIDS didapatkan 1 responden $(3,22 \%)$ memiliki pengetahuan baik, 20 responden $(64,52 \%)$ memiliki pengetahuan cukup dan 10 responden $(32,26 \%)$ responden memiliki pengetahuan kurang.

Penelitian ini sejalan dengan hasil penelitian lain yang menunjukan terdapat pengaruh yang signifikan antara penyuluhan dengan pengetahuan dan sikap dalam mencegah penularan HIV/AIDS dengan nilai $p$-value sebesar $0,000 \quad(\mathrm{p}<0,005)$ (Sulistyaningsih, 2011). Tingkat pengetahuan responden menjadi baik dan cukup karena sudah mendapatkan informasi kesehatan mengenai HIV/AIDS melalui video animasi. Terdapat tiga domain yang dapat dirubah oleh seseorang melalui pendidikan kesehatan yaitu pengetahuan, keterampilan serta sikap (Mubarak, 2009). Pendidikan kesehatan menciptakan peluang bagi individu untuk senantiasa memperbaiki kesadaran (Literacy), serta meningkatkan pengetahuan dan keterampilan (life skill) demi tercapainya kesehatan yang optimal juga menyatakan bahwa proses pembelajaran yang baik maka akan menghasilkan yang baik (Khasanah, 2012). 
Video yang digunakan berupa video animasi. Media animasi terdiri dari kumpulan gambar atau objek yang diolah sedemikian rupa sehingga menghasilkan gerakan dari berbagai objek yang divariasikan dengan efek dan filter, gerakan transisi, suara-suara yang selaras dengan gerakan objek tersebut. Media animasi sebagai bentuk komunikasi yang dapat digunakan untuk menyampaikan informasi dari sumber ke peserta yang bertujuan merangsang mereka untuk mengikuti kegiatan pembelajaran. Animasi memiliki kemampuan untuk dapat memaparkan sesuatu yang rumit atau komplek atau sulit untuk dijelaskan dengan hanya gambar atau kata-kata saja, sehingga dapat digunakan untuk menjelaskan suatu materi yang secara nyata tidak dapat terlihat oleh mata, dengan cara melakukan visualisasi maka materi yang dijelaskan dapat tergambarkan (Andriany, 2016).

Tabel 2. Hasil Analisis Pengaruh Video Edukasi terhadap tingkat pengetahuan tentang HIV/AIDS

\begin{tabular}{lcc}
\hline & Mean SD & P Value \\
Pretest & 17,43 & \\
Posttest & 2,67 & 0,000 \\
\hline
\end{tabular}

Berdasarkan uji Wilcoxon yang dilakukan peneliti, didapatkan nilai $\mathrm{p}$ values sebesar 0.000 , hal ini menunjukkan bahwa terdapat pengaruh pendidikan kesehatan dengan media video terhadap tingkat pengetahuan tentang HIV/AIDS di Lapas Yogyakarta sebelum dan setelah diberikan pendidikan kesehatan. Adanya peningkatan pengetahuan tentang pencegahan HIV/AIDS sebelum dan sesudah diberikan pendidikan kesehatan ini sesuai dengan penelitan yang mengatakan bahwa ada peningkatan nilai rata-rata responden mengenai kesehatan reproduksi antara sebelum dan sesudah diberikan penyuluhan (Kumalasari, 2012). Penelitian ini juga didukung oleh penelitian lain yang mengatakan bahwa pengetahuan mengalami peningkatan yang baik dengan adanya pemberian pendidikan kesehatan dengan penyuluhan (Emilia, 2018).
Hasil perbandingan pengetahuan sebelum dan sesudah pemberian pendidikan kesehatan dengan media video menunjukan bahwa sebelum pemberian pendidikan kesehatan dengan media video terdapat 1 responden $(1,3 \%)$ berpengetahuan baik. Setelah pemberian pendidikan kesehatan dengan media video terjadi peningkatan menjadi 25 responden $(80,64 \%)$ berpengetahuan baik,, 4 responden $(12,90 \%)$ berpengetahuan cukup setelah pemberian pendidikan kesehatan dengan media video dan terdapat 2 responden $(6,45 \%)$ berpengetahuan kurang.

Penelitian ini memiliki hasil yang sejalan dengan penelitian (Tandilangi, Mintjelungan, \& Wowor, 2016) yang menyimpulkan bahwa health education dengan animasi kartun efektif meningkatkan pengetahuan. Penelitian (Maryatun, 2015) juga mendukung hasil penelitian ini, dengan hasil penelitian yaitu rata-rata skor pengetahuan gizi seimbang sebelum pemberian media animasi adalah $36,90 \pm$ 4,22 , sedangkan rata-rata skor pengetahuan gizi seimbang sesudah pemberian media animasi adalah 39,28 \pm 4,76. Hasil penelitian menunjukkan adanya pengaruh pemberian media animasi terhadap perubahan pengetahuan $(\mathrm{p}=0,003)$.

Pendidikan kesehatan merupakan salah satu upaya yang dapat dilakukan untuk melakukan pencegahan HIVAIDS. Metode yang biasa digunakan dalam PKM (Pendidikan Kesehatan Masyarakat) antara lain film, pamflet, leaflet dan ceramah. Kebanyakan pendidikan kesehatan menggunakan metode penyuluhan, karena lebih murah, tidak memerlukan setting tempat yang terlalu rumit dan membutuhkan waktu yang singkat, baik dalam mempersiapkannya maupun pada saat pelaksanaannya (Benita, 2012). Sehingga untuk pencegahan HIV AIDS dengan media video animasi adalah salah satu upaya pencegahan kejadian HIV/AIDS di Lapas.

\section{KESIMPULAN DAN SARAN}

Tingkat pengetahuan responden tentang pencegahan HIV/AIDS pada saat pretest didapatkan jumlah terbanyak dalam kategori cukup dan setelah diberikan media pembelajaran dengan video edukasi meningkat menjadi kategori baik. Dengan 
peningkatan hasil pretest - postest dengan video edukasi HIV AIDS maka berpengaruh terhadap peningkatan pengetahuan $\mathrm{p}<005$.

Saran bagi penghuni lapas perlu ditingkatkan pengetahuan, serta kepedulian tentang kesehatan reproduksi, terutama pengetahuan tentang HIV/AIDS dengan harapan setelah mengetahui informasi kesehatan khususnya HIV/AIDS, para napi dapat melakukan upaya pencegahan untuk diri sendiri dengan memperhatikan kesehatan reproduksi. Perlu ditingkatkan penyebaran informasi tentang HIV/AIDS melalui peran langsung dari petugas kesehatan lapas. Bagi peneliti selanjutnya perlu dilakukan penelitian lanjutan dengan menambah variabel lain seperti variabel sikap HIV/AIDS dengan cakupan responden yang lebih luas dan penggunaan metode lain misalnya dengan peer group dan deep interview.

\section{REFERENSI}

Andriany, P., Novita, C. F., \& Aqmaliya, S. (2016). Perbandingan efektifitas media penyuluhan poster dan kartun animasi terhadap pengetahuan kesehatan gigi dan mulut (Studi pada siswa/i kelas V SDN 24 Kota Banda Aceh). Journal Of Syiah Kuala Dentistry Society, 1(1), 65-72.

Benita, N., Dewantiningrum, J., \& Maharani, N. (2012). Pengaruh penyuluhan terhadap tingkat pengetahuan kesehatan reproduksi pada remaja siswa Smp Kristen Gergaji. Jurnal Kedokteran Diponegoro, 1(1), 106293.

Emilia, O., Prabandari, Y. S., \& Supriyati. (2018). Promosi kesehatan dalam lingkup kesehatan reproduksi. Yogyakarta: Pustaka Cendekia.

Ergene, T., Çok, F., Tümer, A., \& Ünal, S. (2005). A controlled-study of preventive effects of peer education and singlesession lectures on HIV/AIDS knowledge and attitudes among university students in Turkey. AIDS Education and Prevention, 17(3), 268-278.

Khasanah, K., \& Hidayati, W. (2012). Kualitas Tidur Lansia Balai Rehabilitasi Sosial " MANDIRI " Semarang. Jurnal Nursing Studies, 1(1), 189-196. Retrieved from http://ejournal-

s1.undip.ac.id/index.php/jnursing
Kumalasari, I., \& Andhyantoro, I. (2012). Kesehatan reproduksi untuk mahasiswa kebidanan dan keperawatan. Jakarta: Salemba Medika.

Machfoedz, I., \& Suryani, E. (2009). Pendidikan bagian dari promosi kesehatan. Yogyakarta: Fitramaya.

Maryatun, M. (2015). Pengaruh penggunaan media program microsoft powerpoint terhadap hasil belajar strategi promosi pemasaran mahasiswa semester 2 program studi Pendidikan Ekonomi Universitas Muhammadiyah Metro tahun ajaran 2014/2015. PROMOSI (Jurnal Pendidikan Ekonomi), 3(1), 1-13.

Monks, F., A.M.P, K., \& Haditono, S. R. (2004). Psikologi perkembangan. Yogyakarta: Gadjah Mada University Press.

Mubarak, W. I., \& Chayatin, N. (2009). Ilmu kesehatan masyarakat: teori dan aplikasi. Jakarta: Salemba Medika.

Ritianawati. (2010). Tingkat pengetahuan HIVIAIDS dan sikap remaja terhadap perilaku seksual pra nikah di SMA X di Jakarta Timur. Skripsi Program Studi ilmu keperawatan. Depok.

Setiana, L. (2005). Teknik penyuluhan dan pemberdayaan masyarakat. Jakarta: Ghalia Indonesia.

Sholihatun. (2011). Perbedaan Efektivitas Metode Ceramah dan Metode Peer Konselor Terhadap Pengetahuan Remaja Tentang Seks Pra Nikah Pada Siswa Kelas II Multimedia Di Smk Kartini Semarang. Jurnal Komunikasi Kesehatan, 2(2), 4-9.

Sulistyaningsih. (2011). Metodologi penelitian kebidanan kuantitatif-kualitatif. Yogyakarta: Graha Ilmu.

Taher, B., Ticoalu, S., \& Onibala, F. (2013). Pengaruh Pendidikan Kesehatan Terhadap Tingakat Pengetahuan Siswa Tentang Cara Pencegahan Penyakit Hiv/Aids Di Sma Negeri 1 Manado. Jurnal Keperawatan UNSRAT, 1(1), 108942.

Tandilangi, M., Mintjelungan, C., \& Wowor, V. N. S. (2016). Efektivitas dental health education dengan media animasi kartun terhadap perubahan perilaku kesehatan gigi dan mulut Siswa SD Advent 02 Sario Manado. EGIGI, 4(2). 
Vaz, R. G., Gloyd, S., \& Trindade, R. (1996). The effects of peer education on STD and AIDS knowledge among prisoners in Mozambique. International Journal of STD and AIDS, 7(1), 51-54.
Widyastuti, Y., Rahmawati, A., \& Purnamaningrum, Y. (2009). Kesehatan Reproduksi. Yogyakarta: Fitramaya. 